\title{
ENTOMOLOGY
}

\section{First record of Bloodiella Nowicki, 1935 (Hymenoptera: Trichogrammatidae) from Italy}

\author{
G. Viggiani, ${ }^{1}$ F. Filella ${ }^{2}$ \\ ${ }^{1}$ Laboratory of Biological Control, Department of Agriculture, University of Naples "Federico II"; ${ }^{2}$ Agrarian \\ Professional Institute, Spezzano Albanese (CS), Italy
}

\begin{abstract}
From pieces of olive tree leaves with only egg clusters of Macrolenes dentipes (Olivier) (Coleoptera: Chrysomelidae), specimens of the trichogrammatid Bloodiella andalusiaca Nowicki (1935) emerged. This is the first record for the genus and the species from Italy. The original description of $B$. andalusiaca is reviewed and new characters are added. Hosts of this egg parasitoid are unknown, but our observations suggest that $M$. dentipes is a very possible candidate.
\end{abstract}

\section{Introduction}

In the framework of a research on the egg parasitoids of Macrolenes dentipes (Olivier) (Coleoptera: Chrysomelidae), from pieces of olive tree leaves with only egg clusters of the mentioned leaf beetle, females and males of a trichogrammatid emerged. They

Correspondence: Gennaro Viggiani, Laboratorio di Lotta biologica, Dipartimento di Agraria, Università degli Studi di Napoli "Federico II", Via Università, 133, Portici (NA), Italia,

Tel.: +39.081.2539003 - Fax +39.081.7755872.

E-mail: genviggi@unina.it

Key words: andalusiaca, egg cluster, Macrolenes, olive tree.

Contributions: The authors contributed equally.

Conflict of interest: The authors declare no potential conflict of interest.

Funding: None.

Received for publication: 11 October 2019

Accepted for publication: 13 November 2019.

${ }^{\circ}$ Copyright: the Author(s), 2019

Licensee PAGEPress, Italy

Journal of Entomological and Acarological Research 2019; 51:8616

doi:10.4081/jear.2019.8616

This article is distributed under the terms of the Creative Commons Attribution Noncommercial License (by-nc 4.0) which permits any noncommercial use, distribution, and reproduction in any medium, provided the original author(s) and source are credited. were identified as Bloodiella andalusiaca Nowicki (1935). Until now the species was only recorded by its author (Nowicki, 1935, 1940), but not from Italy. In the present paper the original description is reviewed and new important characters are added.

\section{Materials and methods}

In April-May 2019 a severe infestation caused by the leaf beetle M. dentipes occurred in Cassano allo Ionio (CS), locality Silva. Pieces of olive tree leaves with egg clusters of the chrysomelid were collected and isolated in Petri dishes and vials. From this material several parasitoids emerged in June-July of the same year. Among them several specimens of a trichogrammatid were collected and mounted on slide for study and identification, using a microscope Zeiss Axiophot. Photos were taken by using a camera PowerShot $\mathrm{S}$ 45. The nomenclature follows Doutt and Viggiani (1968) and Pinto (2006).

\section{Results}

The 13 specimens of the trichogrammatid collected ( 9 females and 4 males), identified by the first author following Doutt and Viggiani (1968), were identified as Bloodiella andalusiaca Nowicki,1935 (Figure 1A). These specimens were also compared with material of B. andalusiaca collected by S. Nowicki and deposited in the entomological collection of the Dipartimento di Agraria, Università degli Studi di Napoli "Federico II", Portici (NA), Italy. The original description of $B$. andalusiaca is here reviewed.

\section{Bloodiella andalusiaca Nowicki, 1935}

The species was described on a pair (1 female lacking fore wings and 1 male) of specimens collected in Spain and 2 females collected in Turkey. The original description, given in details and supported by good illustrations, is widely confirmed by the morphological characters showed by the Italian material, but lacks information concerning the male genitalia, at present fundamental for a better characterization of both genus and species, and their proper placement in the classification of the Trichogrammatidae. Consequently, the following notes are added. 
FEMALE. Antenna (Figure 1B) with pedicel about as long as funicle, not markedly longer, the single funicle segment asymmetrical, dorsally rather swollen, with 4-6 linear sensilla (Figure 1C); club conic-ovate, not cylindrical, with $\mathrm{C} 1$ and $\mathrm{C} 2$ each with 5-7 linear sensilla on each surface. Mesophragma distally bilobed. Fore wing 1.3-1.5 as long as wide, other characters as in Figure 1D. Gaster slightly longer than mesosoma, ovipositor (Figure 1E) not exerted, as long as hind tibia. Body length: 0.5-0.7 mm.

MALE. Antenna (Figure 2A) with funicular segment not swollen as in the female, about as long as half of the pedicel and without linear sensilla; club conic-ovate $1.6 \times$ as long as wide with 2-3 linear sensilla on one surface of each club segment (Figure 2B). Genitalia with phallobase wider basally, having ventral margin deeply concave, antero-dorsal aperture subtriangular, $0.6 \times$ as long as the total genitalia length; parameres and volsellar digiti lacking; aedeagus without apodemes and with median and lateral rods. Genitalia length: $0.14-0.15 \mathrm{~mm}$.

MATERIAL EXAMINED. $9+$ and $4 \hat{\jmath}$, ITALY: Cassano allo Ionio, locality Silva (CS), 21-30.vi.2019, from pieces of olive tree leaves with egg clusters of Macrolenes dentipes, coll. F. Filella. 39. POLAND: E.K.D. (= Elektryczne Koleje Dojazdowe), Warsaw Grodzisk Mazowiecki, 4-11.vii.1940, coll. S. Nowicki.

Specimens (5 females) of Bloodiella, probably, B. andalusiaca, collected in Sicily by J. D. P., are preserved in the University of California, Riverside.

Distribution. Spain, Turkey (Nowicki, 1935), Poland, Corsica, Southern France and Yugoslavia (Nowicki, 1940), Italy.

Host. The eggs of M.dentipes may be host of $B$. andalusiaca. The only known host record for a species of Bloodiella concerns $B$. gynandrophthalmae (Risbec). This species emerged from eggs of Smaragdina (= Gynandrophthalma) weisei Jac. (Coleoptera: Chrysomelidae, Clytrinae) (Risbec, 1951).

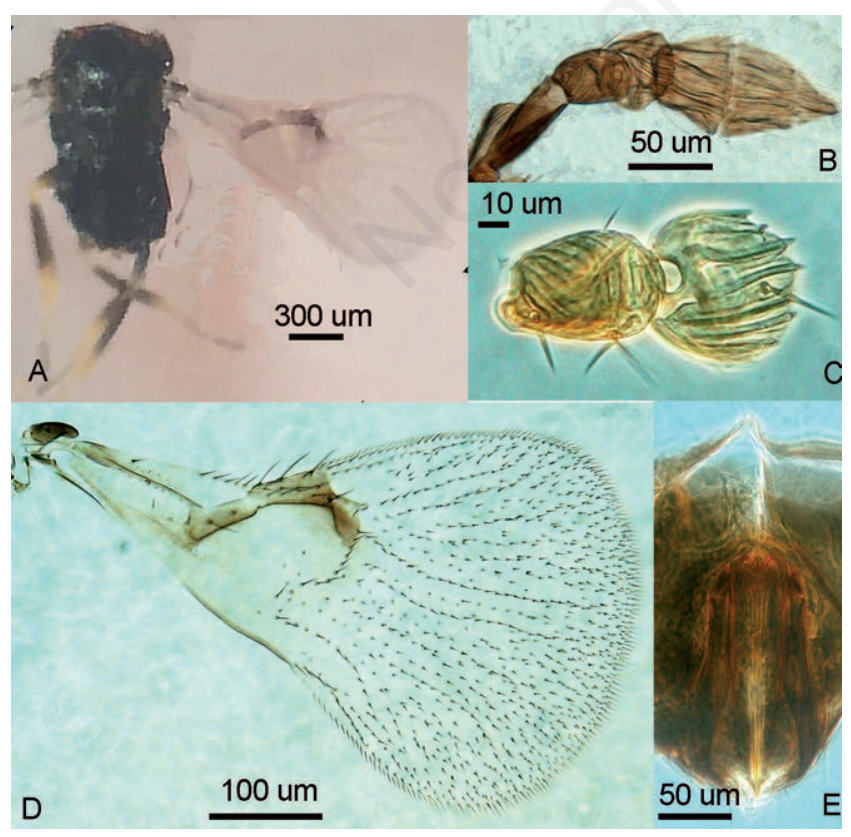

Figure 1. A) Bloodiella andalusiaca, adult; B) Female antenna; C) Pedicel and funicular segment of the female antenna; D) Female fore wing; E) Ovipositor.

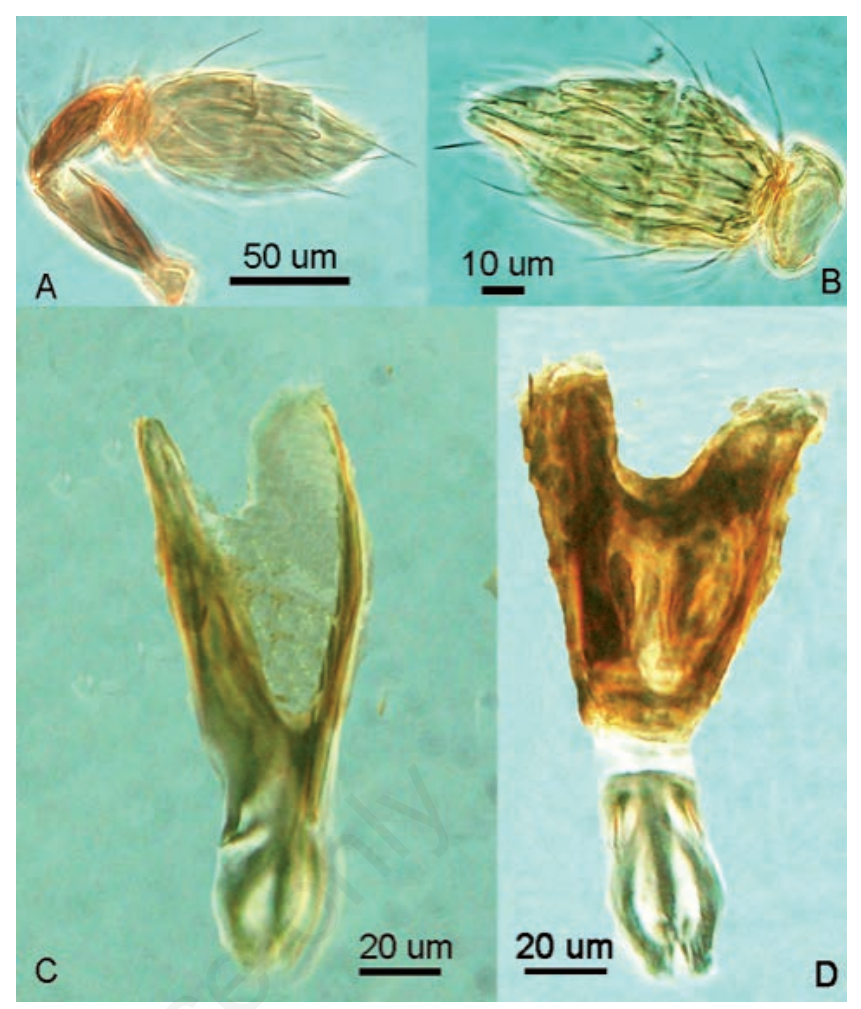

Figure 2. A) Bloodiella andalusiaca, male antenna; B) Funicle and club; C) Genitalia, latero-dorsal view; D) Genitalia, ventral view.

\section{Discussion}

There are three species assigned to the genus Bloodiella, namely, $B$. andalusiaca, Nowicki, $B$. carbonelli De Santis and $B$. gynandrophthalmae (Risbec) but the diagnosis of the genus given by Pinto (2006) was based only on the original description of the type of the genus $B$. andalusiaca. In fact, according to the opinion of the latter author, the assignment of the other species is uncertain and perhaps erroneous. The nearest genus to Bloodiella is the resurrected genus Burksiella De Santis (Pinto, 2006). At present their distinction is based only on the presence of two funicular segments in the latter genus, with the first one, in some species (B. dianae Pinto) very small and closely appressed to the second one. The material examined in the present paper allowed to clarify some morphological details of $B$. andalusiaca and consequently the diagnosis of the genus Bloodiella. It is confirmed that the rather swollen and transverse funicle is represented by only one segment and that the sensorial equipment of the female antenna (funicle and club) is richer in comparison to that of the male. In addition, the shape and structure of the male genitalia, here described and illustrated for the first time, are markedly different from those in Burksiella described by Pinto (2006).

The genitalia of $B$. andalusiaca have same shape and structure of those described for B. gynandrophthalmae (Risbec) (Viggiani, 1969), supporting the correct assignment of the latter species to Bloodiella and that of this genus to the tribe Chaetostrichini (Viggiani, 1971). The phallobase in Bloodiella recalls that found in several species of Ufens (acacia, ceratus, kender, noyesi, parvimalis, placoides, thylacinus and others), in which, however, parameres and digital volsellae are present (Owen, 2011). 


\section{References}

DOUTT R.L., VIGGIANI G., 1968 - The classification of the Trichogrammatidae (Hym. Trichogrammatidae). Proc. Calif. Acad. Sci. 35: 477-586.

NOWICKI S., 1935 - Descriptions of new genera and species of the family Trichogrammidae (Hym. Chalcidoidea) from the Palaearctic region, with notes - I. - Z. Angew. Entomol. 21: 566-596.

NOWICKI S., 1940 - Descriptions of new genera and species of the family Trichogrammatidae (Hym. Chalcidoidea) from the Palearctic Region, with notes-Supplement. - Z. Angew. Entomol. 26: 624-663.

NOYES J S., 2018 - Universal Chalcidoidea Database. Available from: www.nhm.ac.uk/entomology/chalcidoids/index.html
OWEN A.K., 2011 - Revision of Ufens Girault, 1911 (Hymenoptera: Trichogrammatidae). - Univ. Calif. Publ. Entomol. 131: 1-164.

PINTO J.D., 2006 - A review of the New World genera of Trichogrammatidae (Hymenoptera). - J. Hymenopt. Res. 15: 38-163.

RISBEC J., 1951 - Les Chalcidoides de l'Afrique occidentales française. - Mémoires de 108 l'Institut Français d'Afrique Noire, Ifan-Dakar 13: 397- 400.

VIGGIANI G., 1969 - Ridescrizione dei Trichogrammatidae descritti da J. Risbec. Ricerche sugli Hymenoptera Chalcidoidea. XXII. - Bollettino del Laboratorio di Entomologia Agraria "Filippo Silvestri” 27: 187-209.

VIGGIANI G., 1971 - Studio morfologico comparativo dell'armatura genitale esterna maschile dei Trichogrammatidae. Ricerche sugli Hymenoptera Chalcidoidea. XXVIII. Bollettino del Laboratorio di Entomologia Agraria "Filippo Silvestri” 29: 181-222. 